\title{
Contamination by pathogenic multidrug resistant bacteria on interior surfaces of
}

\section{ambulances}

\section{Contaminação por bactérias patogênicas multirresistentes em superfícies internas de ambulâncias \\ Contaminación por bacterias patógenas multirresistentes en superficies interiores de ambulancias}

\begin{abstract}
Pre-hospital emergency care is a healthcare delivery service to victims of illnesses or accidents with a wide variety of health profiles. Ambulances may be a source of pathogenic microorganisms if not sanitized properly. Considering this, the present study aimed to evaluate the bacterial community present in different equipment and surfaces from ambulances used on pre-hospital care and verify the antibiotic resistance profile of the isolates. For that, three ambulances were chosen in unannounced visits, and eight sampling points were selected: wall inside the vehicle, cervical collar, spinal boards, bedsheets, masks, earplugs, head blocks and steering wheels. Pathogenic bacteria were isolated, identified and submitted to antimicrobial assays. A total of 144 samples were collected, and 33 different bacteria species were isolated. Among them, pathogenic genera Staphylococcus, Acinetobacter, Listeria and Ewingella. Staphylococcus, Acinetobacter, Listeria presented strains resistant to oxacilin, isolated from earplugs, spinal boards and masks which are in frequent contact with patients and rescuers. The results highlight the presence of pathogenic bacteria on surfaces and equipment that had been cleaned and deemed free of contagion.
\end{abstract}

Keywords: Drug resistance; Ambulances; Rescue; Public health; Acinetobacter.

\section{Resumo}

O atendimento pré-hospitalar de emergência é um serviço de atendimento às vítimas de doenças ou acidentes com os mais variados perfis de saúde. As ambulâncias podem ser uma fonte de micro-organismos patogênicos se não forem devidamente higienizadas. Diante disso, o presente estudo teve como objetivo avaliar a comunidade bacteriana presente em diferentes equipamentos e superfícies de ambulâncias utilizadas no atendimento pré-hospitalar e verificar o perfil de resistência aos antibióticos dos isolados. Para tanto, foram escolhidas três ambulâncias em visitas não anunciadas, e selecionados oito pontos de amostragem: parede interna do veículo, colar cervical, macas, lençóis, máscaras, olivas, bloqueios de cabeça e volante. Bactérias patogênicas foram isoladas, identificadas e submetidas a ensaios antimicrobianos. Um total de 144 amostras foram coletadas e 33 espécies diferentes de bactérias foram isoladas. Entre eles, os gêneros patogênicos Staphylococcus, Acinetobacter, Listeria e Ewingella. Staphylococcus, Acinetobacter, Listeria apresentaram cepas resistentes à oxacilina, isoladas de olivas, macas e máscaras que estão em contato frequente com pacientes e socorristas. Os resultados destacam a presença de bactérias patogênicas em superfícies e equipamentos que foram limpos e considerados livres de contágio.

Palavras-chave: Resistência bacteriana; Ambulâncias; Resgate; Saúde pública; Acinetobacter. 


\section{Resumen}

La atención prehospitalaria de urgencias es un servicio de prestación de asistencia sanitaria a víctimas de enfermedades o accidentes con una amplia variedad de perfiles de salud. Las ambulancias pueden ser una fuente de microorganismos patógenos si no se desinfectan adecuadamente. Considerando eso, el presente estudio tuvo como objetivo evaluar la comunidad bacteriana presente en diferentes equipos y superficies de ambulancias utilizadas en la atención prehospitalaria y verificar el perfil de resistencia antibiótica de los aislados. Para ello, se eligieron tres ambulancias en visitas no anunciadas y se seleccionaron ocho puntos de muestreo: pared interior del vehículo, collarín cervical, tableros espinales, sábanas, mascarillas, tapones para los oídos, cabeceros y volantes. Las bacterias patógenas fueron aisladas, identificadas y sometidas a ensayos antimicrobianos. Se recogieron un total de 144 muestras y se aislaron 33 especies diferentes de bacterias. Entre ellos, los géneros patógenos Staphylococcus, Acinetobacter, Listeria y Ewingella. Staphylococcus, Acinetobacter, Listeria presentaron cepas resistentes a la oxacilina, aisladas de tapones para los oídos, tableros espinales y máscaras que están en contacto frecuente con pacientes y rescatistas. Los resultados destacan la presencia de bacterias patógenas en superficies y equipos que habían sido limpiados y considerados libres de contagio

Palabras clave: Farmacorresistencia bacteriana; Ambulancias; Rescate; Salud pública; Acinetobacter.

\section{Introduction}

Pre-hospital emergency care is a coordinated and timely delivery of healthcare services to victims of illnesses or accidents (Hudson et al., 2017). The service provides 24 hours care for urgent and emergency health problems, helping everyday thousands of patient in different situations outside the hospital, transporting them with ambulances. Patients transported to hospitals or other health facilities by this system may have infections; therefore, after each run, ambulances must be cleaned and decontaminated to be ready for its next use (Sheahan et al., 2019).

The relevance of this cleaning and decontamination process lies in the fact that uncleaned ambulances can be a source of pathogenic organisms such as influenza virus, severe acute respiratory syndrome (SARS), coronavirus, meningococcal meningitis, methicillin-resistant Staphylococcus aureus (MRSA), Mycobacterium tuberculosis, and vancomycin-resistant enterococci (Kampf et al., 2020; Miramonti et al., 2013). Patients and rescuers can be contaminated during the assistance by direct contact with the surfaces or equipment (Varona-Barquin et al., 2017), and become a source of cross-contamination between ambulances and hospital environments (Russotto et al., 2015). Nonetheless, infection control of pre-hospital emergency care services has not yet been recognized as an essential part of public health (Noh et al., 2011), which could become a critical problem during a pandemic event.

Once that evidence of contamination of surfaces and equipment in pre-hospital emergency care services is little known, and the prevalence and virulence of multiple-drug-resistant organisms has increased, it becomes important to limit exposure conditions, identify the most contaminated sites and which microorganisms are present, and eradicate contamination by using appropriate disinfection and sanitation procedures (Russotto et al., 2015).

Considering the lack of research on these services, the present study aims to evaluate the bacterial community present in different equipments and surfaces from emergency ambulances ready for service used on pre-hospital care and verify the antimicrobial resistance profiles of the isolates of clinical importance.

\section{Methodology}

\subsection{Study design and setting}

The study was developed on a rescue station, in unannounced visits. Three ambulances were chosen, and eight sampling points inside each ambulance were selected based on their frequency of contact with rescuers and patients, and then divided into: a) direct contact: cervical collar, spinal boards, bedsheets, masks, earplugs, head blocks; b) indirect contact: wall inside the vehicle and steering wheel. Samples were collected from August 2017 to April 2018, totalizing 144 samples. 


\subsection{Bacteria sampling and identification}

Surfaces were sampled using swabs moistened with sterile saline solution $(0.9 \% \mathrm{NaCl})$. During the sampling process, swabs were rubbed over the entire sampling point and rotated to collect as much material as possible. Swabs were inserted into sterile tubes containing BHI broth (Becton Dickinson $\mathrm{GmbH}$, Heidelberg, Germany) and incubated for $24 \mathrm{~h}$ at $37^{\circ} \mathrm{C}$. Subsequently, the enriched cultures were streaked onto mannitol salt agar and MacConkey's agar, and incubated for $24 \mathrm{~h}$ at $37^{\circ} \mathrm{C}$. Isolated colonies were regrown on nutrient agar, and then biochemically identified by the following tests: motility; indole production; hydrogen sulphide production; lactose, glucose and sucrose fermentation; use of citrate as sole carbon source; urease and catalase enzyme production; and decarboxylation of lysine and ornithine. Bacteria were identified with the Advanced Bacterial Identification Software (ABIS Online), where only scores above 95\% of identification were considered.

\subsection{Antibiotic sensitiveness profile}

Antibiotic sensitiveness was performed on Mueller Hinton agar by the Kirby Bauer's disk diffusion method (James \& Biemer, 1973) using the following antibiotics (CECON industry): oxacillin $(1 \mu \mathrm{g})$, ciprofloxacin $(5 \mu \mathrm{g})$ and sulfamethoxazole/trimethoprim $(25 \mu \mathrm{g})$. The inhibition zone was measured using the EUCAST Version 9.0 (EUCAST 2019) interpretation. These antibiotics were chosen because they are important on treating human bacterial infections (Sayah et al., 2005).

\subsection{Statistical analysis}

The results were statistically analyzed by the Pearson's chi-squared test. The chi-squared test was used to evaluate the correlation between contamination by bacteria (considering all species identified), sampled sites and the type of contact (direct or indirect) with the surface. Then it was applied to evaluate the association between the frequency of pathogenic bacteria and the surfaces studied. The dummy variable was established as 1 (for pathogenic bacteria) and 0 (for non-pathogenic bacteria). All tests were applied with $95 \%$ of confidence ( $p<0.05$ ). All test were performed on the Stata ${ }^{\circledR}$ software.

\section{Results}

Of the 144 samples collected, $121(84 \%)$ tested positive for bacterial contamination (Figure 1). Each ambulance presented an average of $40 \pm 4.7$ positive samples. A total of 33 bacteria species were isolated and identified, and another 19 could not be identified. However, the chi-square test indicated that there is no association between the positive sample and the site where they were found (chi-square $=173.3, p>0.05$ ). 
Figure 1. Number of positive samples for bacteria on ambulance equipment and surfaces.

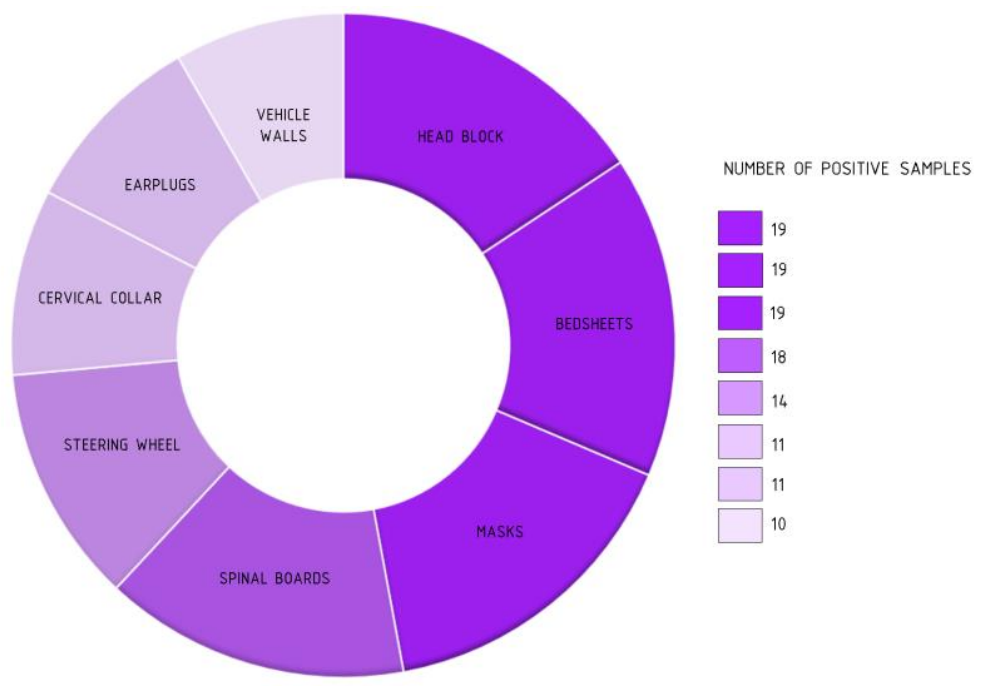

Source: Authors.

Four human pathogenic genera were identified: Staphylococcus, Acinetobacter, Listeria and Ewingella (Figure 2), with a positive correlation between the frequency of pathogenic bacteria contamination on earplugs, spinal boards and masks (Table 1), but there was no association with direct or indirect contacts (chi-square $=0.689, p>0.05)$.

Table 1. Pearson's correlation test considering the presence of pathogenic bacteria on the sampling sites.

\begin{tabular}{|c|c|c|c|c|c|c|c|c|c|}
\hline & $\begin{array}{c}\text { Pathogenic } \\
\text { bacteria }\end{array}$ & $\begin{array}{l}\text { Inside the } \\
\text { wall }\end{array}$ & Earplugs & $\begin{array}{c}\text { Cervical } \\
\text { collar }\end{array}$ & Bedsheets & $\begin{array}{l}\text { Head } \\
\text { blocks }\end{array}$ & $\begin{array}{l}\text { Spinal } \\
\text { boards }\end{array}$ & $\begin{array}{c}\text { Steering } \\
\text { wheels }\end{array}$ & Masks \\
\hline $\begin{array}{l}\text { Pathogenic } \\
\text { bacteria }\end{array}$ & 1 & & & & & & & & \\
\hline Inside the wall & -0.120 & 1 & & & & & & & \\
\hline Earplugs & 0.102 & -0.0177 & 1 & & & & & & \\
\hline Cervical collar & -0.134 & 0.229 & 0.0887 & 1 & & & & & \\
\hline Bedsheet & -0.107 & 0.139 & 0.0983 & 0.0725 & 1 & & & & \\
\hline Head blocks & -0.175 & 0.0563 & 0.0853 & -0.223 & 0.107 & 1 & & & \\
\hline Spinal boards & 0.0141 & 0.191 & -0.120 & 0.0122 & 0.0507 & -0.130 & 1 & & \\
\hline $\begin{array}{l}\text { Steering } \\
\text { wheels }\end{array}$ & -0.0650 & 0.480 & 0.222 & 0.0282 & 0.469 & 0.455 & 0.389 & 1 & \\
\hline Masks & 0.0115 & 0.304 & 0.478 & 0.0925 & 0.316 & 0.464 & 0.0831 & 0.544 & 1 \\
\hline
\end{tabular}

Source: Authors. 
Figure 2. Relative abundance of pathogenic bacteria present in different surfaces and equipment inside the ambulance vehicles.

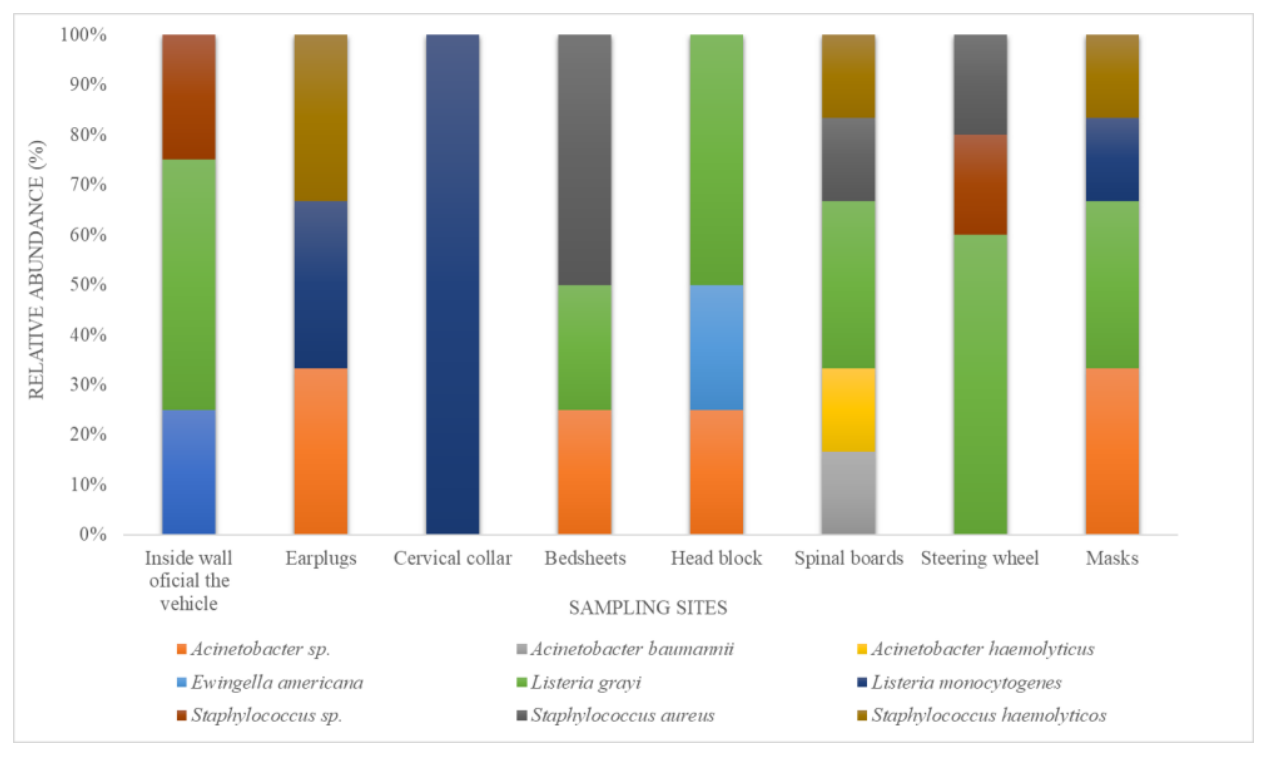

Source: Authors.

The isolates classified as of clinical importance were submitted to antibiotic susceptibility test and the results are presented on Table 2 .

Table 2. Antibiotic susceptibility profile from the pathogenic bacteria isolated from ambulance internal surfaces and equipment.

\begin{tabular}{lcccccc}
\hline \multicolumn{1}{c}{ Bacteria } & \multicolumn{5}{c}{ Antibiotic/Halo (mm) } \\
\hline & \multicolumn{2}{c}{ Oxacillin } & \multicolumn{2}{c}{ Ciprofloxacin } & Sulfamethoxazole \\
\cline { 2 - 6 } Acinetobacter sp. & 6 & $\mathrm{R}$ & $>30$ & $\mathrm{~S}$ & 30 & $\mathrm{~S}$ \\
Acinetobacter baumannii & 20 & $\mathrm{R}$ & $>30$ & $\mathrm{~S}$ & $>30$ & $\mathrm{~S}$ \\
Acinetobacter haemolyticus & 28 & $\mathrm{~S}$ & 30 & $\mathrm{~S}$ & $>30$ & $\mathrm{~S}$ \\
Ewingella americana & 24 & $\mathrm{~S}$ & $>30$ & $\mathrm{~S}$ & $>30$ & $\mathrm{~S}$ \\
Listeria grayi & 6 & $\mathrm{R}$ & 20 & $\mathrm{R}$ & 30 & $\mathrm{~S}$ \\
Listeria monocytogenes & 22 & $\mathrm{R}$ & 30 & $\mathrm{~S}$ & 30 & $\mathrm{~S}$ \\
Staphylococcus sp. & 28 & $\mathrm{~S}$ & $>30$ & $\mathrm{~S}$ & 30 & $\mathrm{~S}$ \\
Staphylococcus aureus & 18 & $\mathrm{R}$ & $>30$ & $\mathrm{~S}$ & $>30$ & $\mathrm{~S}$ \\
Staphylococcus haemolyticos & 20 & $\mathrm{R}$ & $>30$ & $\mathrm{~S}$ & $>30$ & $\mathrm{~S}$ \\
\hline
\end{tabular}

R: resistant; S: susceptible. Source: Authors.

Ciprofloxacin and sulfamethoxazole were more efficient in their antibacterial purposes, except in the presence of Listeria grayi. Regarding the oxacillin, $66 \%$ of the isolates strains showed resistance profile, and among them the genera Staphylococcus, Acinetobacter and Listeria. The isolates of E. americana were sensitive to all antibiotic tested.

\section{Discussion}

The genera Staphylococcus is an opportunistic pathogen known for its ability to evade the immune system and cause a variety of different infections (Pollitt et al., 2018), including bacteremia, endocarditis, and skin and pleuro-pulmonary 
infections (Gordon et al., 2019). Staphylococcus aureus is of special concern, once that the World Health Organization (WHO) recently categorized them as of high priority threat in terms of resistance on global a level (Haaber et al., 2017). Methicillinresistant Staphylococcus aureus (MRSA) has spread globally and account for approximately 59\% of skin infections (Haaber et al., 2017). It is estimated that up to half of the world's adult population carries S. aureus in mucous membranes; healthcare professionals, people who regularly use needles (diabetics and intravenous drug users), hospitalized patients and immunocompromised individuals tend to have higher colonization rates (up to 80\%). S. aureus can be transmitted from person to person by direct or indirect contact (Tong et al. 2015), as by touching a steering wheel (Eibicht \& Vogel, 2011). Additionally, ambulance contamination by MRSA strains has been reported even in transportations as short as 20 min (Eibicht \& Vogel, 2011).

Acinetobacter spp. have emerged in recent years as a multidrug or extensively drug resistant strain, and it is a major cause of healthcare-associated infections and hospital outbreaks, especially in intensive care unit patients (Zarrilli et al., 2018), where mortality rates reach $43 \%$ (Asif et al., 2018). Acinetobacter baumannii (A. baumannii) infections account for $\sim 2 \%$ of all healthcare-associated infections in the United States and Europe; however, these rates are twice higher in Asia and in the Middle East (Almasaudi, 2018). Additionally, out of all A. baumannii isolated globally, 45\% are considered multidrug resistant (Zarrilli et al., 2013). This is aggravated by the bacteria's ability to survive on dry surfaces with limited nutrients available for up to 4 months (Almasaudi, 2018).

The Listeria genus are intracellular pathogens often associated with foodborne infections, and it can be fatal for children, pregnant women, elderly and immunocompromised individuals (Caldron et al., 2015). In addition, L. monocytogenes causes severe food poisoning in humans, systemic sepsis, liver abscess, and acute meningitis, which can increase the mortality rate by about 30\% for each hour that correct treatment is delayed. In pregnant women, it can cross the placental barrier and lead to abortion or neonatal infection (Caldron et al., 2015). Its high pathogenicity, biofilm-forming capacity and omnipresence qualify L. monocytogenes as a huge risk to human health (Santos et al., 2019; Olaimat et al., 2018). Listeriosis has been described as the third cause of death from foodborne contamination (Wadhwa et al., 2017).

The Ewingella genus has been associated with peritonitis, bacteremia, fatal cases of nosocomial pneumonia and Waterhouse-Friderichsen syndrome (Spagnolo et al., 2019). Ewingella americana is considered resistant to several $\beta$ lactamases, mainly those from cefalosporins of first and second generation, but sensitive to third and fourth generation drugs from the same group (Esposito et al., 2019).

The results highlight the need for careful disinfection procedures, once that these sites have the highest degree of contact with the body of the patients; thus, they are exposed to pathogens capable of initiating an infection before they reach the hospital (Farhadloo et al., 2018). Additionally, there is huge concern about rescuers, as they stay for extended periods of time in ambulances and some pathogens can have multiple entrance pathways, such as mucous membranes from the respiratory tract, through the skin or another parenteral route (Esposito et al., 2019).

Bacterial contamination on surfaces and equipment of ambulance vehicles is a health problem that happens around the world, because it can play a role in cross-transmitting pathogens that can lead to infection or colonization, and this colonization can generate a possible reservoir of multidrug-resistant pathogens (Russotto et al., 2017). Additionally, the pathogenic genera isolated from these places are capable to form biofilms, and this is one of the key factors that allow bacteria to resist to cleaning products and survive in the environment for a long time (Qi et al., 2016).

Antibiotic resistance is considered a major threat to global health, resulting in increased mortality rates, longer hospital recovery time, and higher medical costs (Shrestha et al., 2018). Therefore, as patients transported by ambulances are often in critical condition, care must be taken to avoid the presence of antibiotic resistant contaminants (El-Mokhtar \& Hetta, 2018). 
Each new emergency service can become a new source of contamination, and considering that ambulances cannot be a sterile environment, continuous pathogens monitoring becomes necessary (Farhadloo et al., 2018). Although it is not possible to associate cases of infections with their onset in ambulances, the present study results highlight the pathogenic bacteria presence on already cleaned surfaces and equipment, showing the vulnerability of users and rescuers in these environments.

\section{Conclusion}

The present study evaluated the bacterial community present in ambulances, and the antibiotic resistance profile from the isolates of clinical importance. The results showed that $84 \%$ from the samples presented positive contamination, with 33 bacteria species, and four pathogenic genera: Staphylococcus, Acinetobacter, Listeria and Ewingella. There was a positive correlation between the presence of pathogenic strains with the earplugs, spinal board and mask surfaces. Staphylococcus, Acinetobacter, Listeria presented strains resistant to oxacilin.

This scenario of contamination has been observed in ambulances worldwide and in different surfaces inside de vehicle, suggesting that in a near future the effectiveness of cleaning protocols need to be improved. Therefore, we recommend training and education programs to rescuers and professionals that work on frontline healthcare, for cleaning and disinfection procedures implementation, once ambulances are key points of the infection control strategies.

\section{References}

Almasaudi, S. B. (2018). Acinetobacter spp. as nosocomial pathogens: Epidemiology and resistance features. Saudi Journal of Biological Sciences, 25, 586596.

Asif, M., Alvi, I. A., \& Rehman, S. U. (2018). Insight into Acinetobacter baumannii: pathogenesis, global resistance, mechanisms of resistance, treatment options, and alternative modalities. Infection and Drug Resistance, 11, 1249-1260.

Caldron, P. H., Impens, A., Pavlova, M., \& Groot, W. (2015). A systematic review of social, economic and diplomatic aspects of short-term medical missions. BMC Health Services Research, 15 (380), 1-10.

Eibicht, S. J., \& Vogel, U. (2011). Meticillin-resistant Staphylococcus aureus (MRSA) contamination of ambulance cars after short term transport of MRSAcolonised patients is restricted to the stretcher. Journal of Hospital Infection, 78, 221-225.

El-Mokhtar, M. A., \& Hetta, H. (2018). Ambulance vehicles as a source of multidrug-resistant infections: a multicenter study in Assiut City, Egypt. Infection and Drug Resistance, 11, 587-594.

Esposito, S., Miconi, F., Molinari, D., Savarese, E., Celi. F., Marchese, L., Valloscuro, S., Miconi, G., \& Principi, N. (2019). What is the role of Ewingella americana in humans? A case report in a healthy 4-year-old girl. BMC Health Services Research, 19, 386.

EUCAST - The European Committee on Antimicrobial Susceptibility Testing. (2019). MIC determination of non-fastidious and fastidious organisms. In:

Broth microdilution - EUCAST Read.

http://www.eucast.org/fileadmin/src/media/PDFs/EUCAST_files/Disk_test_documents/2019_manuals/Reading_guide_BMD_v_1.0_2019.pdf

Farhadloo, R., Goodarzi, Far. J., Azadeh, M., R., Shams, S., \& Parvaresh-Masoud, M. (2018). Evaluation of Bacterial Contamination on Prehospital Ambulances Before and After Disinfection. Prehospital and Disaster Medicine, 33, 602-606.

Gordon, O., Cohen, M. J., Gross, I., Amit, S., Averbuch, D., Engelhard, D., ... Moses, A., (2019). Staphylococcus aureus Bacteremia in Children. The Pediatric Infectious Disease Journal, 38, 459-463.

Haaber, J., Penadés, J., R., \& Ingmer, H. (2017). Transfer of Antibiotic Resistance in Staphylococcus aureus. Trends in Microbiology, 25, 893-905.

Hudson, A., J., Glaister, G., D., \& Wieden, H., J. (2017). The Emergency Medical Service Microbiome. Applied and Environmental Microbiology, 84 (5), 114.

James, J., \& Biemer, M., D. (1973). Antimicrobial Susceptibility Testing by the Kirby-Bauer Disc Diffusion Method. Annals of Clinical \& Laboratory Science, 3,135-140

Kampf, G., Todt, D., Pfaender, S., \& Steinmann, E. (2020). Persistence of coronaviruses on inanimate surfaces and their inactivation with biocidal agents. Journal of Hospital Infection, 104, 246-251.

Miramonti, C., Rinkle, J., A., Iden, S., Lincoln, J., Huffman, G., Riddell, E., \& Kozak, M., A. (2013). The Prevalence of Methicillin-Resistant Staphylococcus Aureus among Out-of-Hospital Care Providers and Emergency Medical Technician Students. Prehospital Emergency Care, $17,73-77$. 
Noh, H., Shin, S. D., Kim, N. J., Ro, Y. S., Oh, H. S., Joo, S. I., ... \& Ong, M. E. H. (2011). Risk stratification-based surveillance of bacterial contamination in metropolitan ambulances. Journal of Korean medical science, 26(1), 124-130.

Olaimat, A. N., Al-Holy, M. A., Shahbaz, H. M., Al-Nabulsi, A. A., Abu Ghoush, M. H., Osaili, T. M., ... \& Holley, R. A. (2018). Emergence of antibiotic resistance in Listeria monocytogenes isolated from food products: a comprehensive review. Comprehensive Reviews in Food Science and Food Safety, 17(5), $1277-1292$

Pollitt, E., J., G., Szkuta, P., T., Burns, N., \& Foster, S., J. (2018). Staphylococcus aureus infection dynamics. PLOS Pathogens, 14 , e1007112.

Qi, L., Li, H., Zhang, C., Liang, B., Li, J., Wang, L., ... \& Song, H. (2016). Relationship between antibiotic resistance, biofilm formation, and biofilm-specific resistance in Acinetobacter baumannii. Frontiers In Microbiology, 7, 483.

Russotto, V., Cortegiani, A., Fasciana, T., Iozzo, P., Raineri, S. M., Gregoretti, C., ... \& Giarratano, A. (2017). What healthcare workers should know about environmental bacterial contamination in the intensive care unit. BioMed Research International, 2017, 1-7.

Russotto, V., Cortegiani, A., Raineri, S. M., \& Giarratano, A. (2015). Bacterial contamination of inanimate surfaces and equipment in the intensive care unit. Journal of intensive care, 3(1), 54 .

Santos, T., Viala, D., Chambon, C., Esbelin, J., \& Hébraud, M. (2019). Listeria monocytogenes biofilm adaptation to different temperatures seen through shotgun proteomics. Frontiers in nutrition, 6, 89.

Sayah, R. S., Kaneene, J. B., Johnson, Y., \& Miller, R. (2005). Patterns of antimicrobial resistance observed in Escherichia coli isolates obtained from domestic-and wild-animal fecal samples, human septage, and surface water. Applied and environmental microbiology, 71(3), 1394-1404.

Sheahan, T., Hakstol, R., Kailasam, S., Glaister, G. D., Hudson, A. J., \& Hans-Joachim Wieden. (2019). Rapid metagenomics analysis of EMS vehicles for monitoring pathogen load using nanopore DNA sequencing. PLoS One, 14, e0219961.

Shrestha, P., Cooper, B. S., Coast, J., Oppong, R., Thuy, N. D. T., Phodha, T., \& Lubell, Y., (2018). Enumerating the economic cost of antimicrobial resistance per antibiotic consumed to inform the evaluation of interventions affecting their use. Antimicrobial Resistance \& Infection Control, 7, 98.

Mondello, C., Roccuzzo, S., Stassi, C., Cardia, L., Grieco, A., \& Raffino, C. (2019). A unique fatal case of Waterhouse-Friderichsen syndrome caused by Proteus mirabilis in an immunocompetent subject: Case report and literature analysis. Medicine, 98(34), e16664-e16664.

Tong, S. Y., Davis, J. S., Eichenberger, E., Holland, T. L., \& Fowler, V. G. (2015). Staphylococcus aureus infections: epidemiology, pathophysiology, clinical manifestations, and management. Clinical microbiology reviews, 28(3), 603-661.

Varona-Barquin, A., Ballesteros-Peña, S., Lorrio-Palomino, S., Ezpeleta, G., Zamanillo, V., Eraso, E., \& Quindós, G. (2017). Detection and characterization of surface microbial contamination in emergency ambulances. American journal of infection control, 45(1), 69-71.

Wadhwa Desai, R., \& Smith, M. A. (2017). Pregnancy-related listeriosis. Birth defects research, 109(5), 324-335.

Zarrilli, R., Bagattini, M., Esposito, E. P., \& Triassi, M. (2018). Acinetobacter infections in neonates. Current infectious disease reports, $20(12), 48$.

Zarrilli, R., Pournaras, S., Giannouli, M., \& Tsakris, A. (2013). Global evolution of multidrug-resistant Acinetobacter baumannii clonal lineages. International journal of antimicrobial agents, 41(1), 11-19. 